
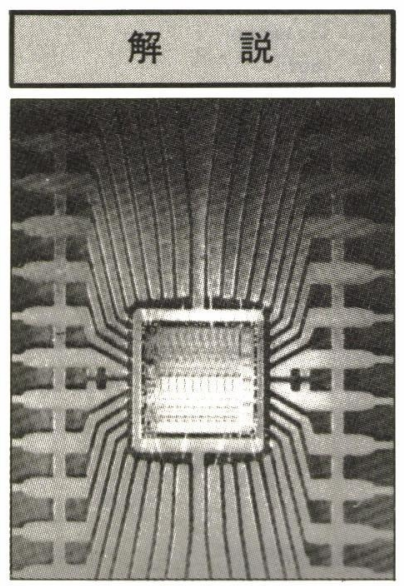

\title{
VLSI とハイブリッドIC
}

その課題と対策

\section{清水 英治*}

\section{1.半導体ICとハイブリッドIC}

Fig.1にICの分類を示したが，半導体IC，ハイブリッ ドICいずれもシステムないし回路の高機能化に伴う小形 化への要請に対して考えられた高密度化の手法であるこ

とは周知である。

$$
\text { エレクトロニクス分野でのデジタル化の進展につれ }
$$

て,この両者における高密度化も著しい発展がみられる。 まず，半導体ICであるが，現在のところ結晶技術と不 純物制御技術を基盤として平面（2-Dimensional）上での 微細化が図られている。Fig. 2 はMOS ICにおける微細 化の変遷をプロセスとの対比で示したものである。

半導体ICでは高密度化の尺度である集積度については ムーアの法則，すなわち，「1個のチップに集積される 素子数は年率 2 倍で増加する」に沿った形で実現されて いるが，そのためにプロセス上での大幅な改良開発が行 われていることがよく分る。今後さらに進展する微細化

（サブミクロン領域）に対応して種々の斬新的な試みが

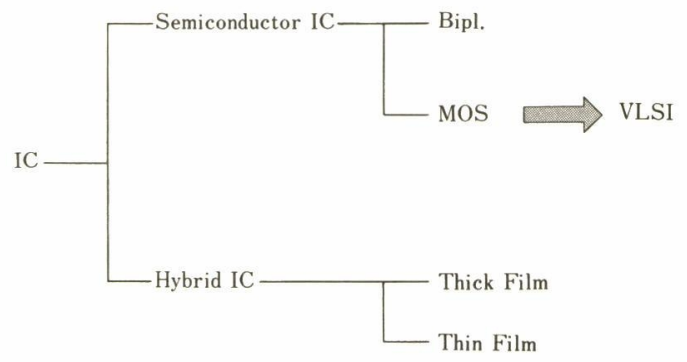

Fig. 1 Classification of IC

*Eiji Shimizu/日本電気
ためされており，また高密度化に対しては従来のScalingのみならず積み重ね手法 (3-Dimensional Approarch）も研究されている。

一方，ハイブリッドICにおける高密度化の進展も著し いが, ハイブリッドICの場合は上に述べた半導体ICの高

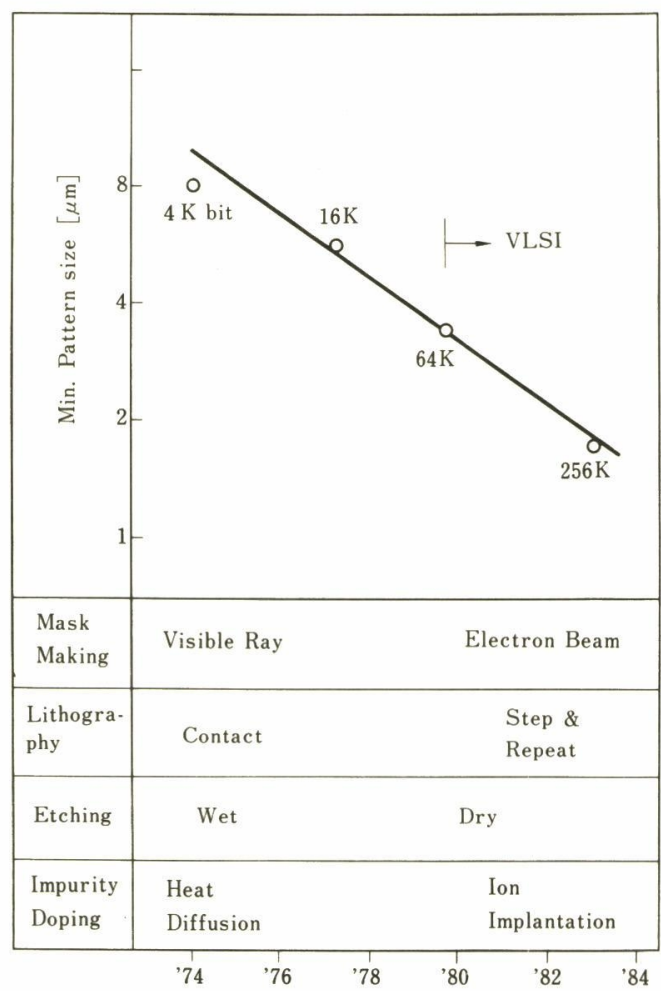

Fig. 2 Progress in Memory Device \& Process Technology (NEC, Tech. Journål, Vol.37 No.8/'84) 

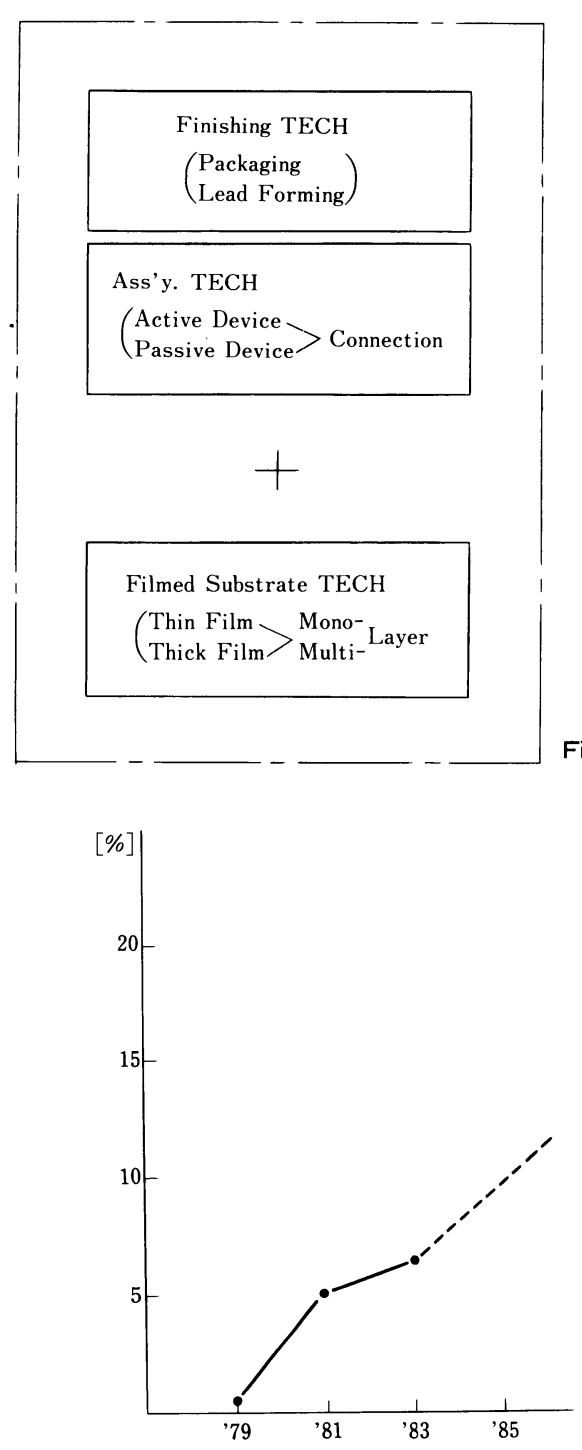

Fig. 5 Changes in Ratio of Multilayer substrates constituting of HICS (NEC, Products Base)

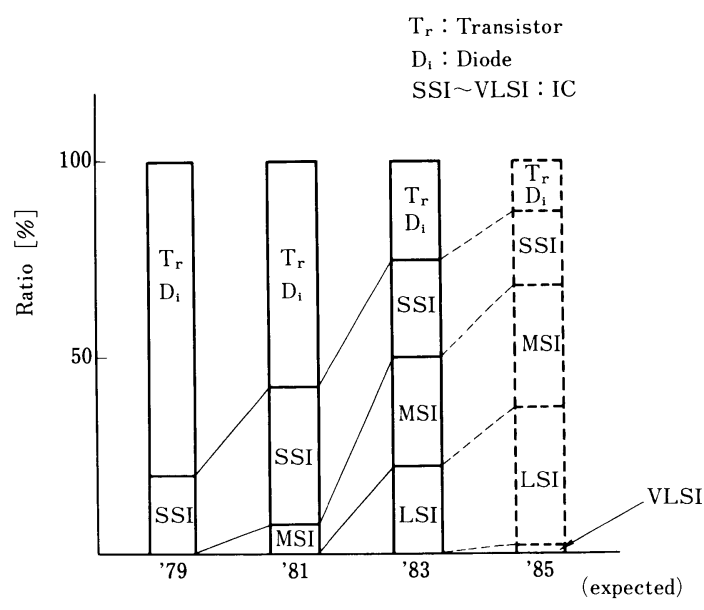

Fig. 4 Changes in Ratio of Active Devices constituting of HICS (NEC, Q'ty. Base)

Fig. 3 Concept of HIC Technology

$$
\text { Density }=\frac{\text { NO. OF }\left(\text { Semiconductor elements }{ }^{*}+\mathrm{C}+\mathrm{R}\right)}{\text { Substrate Area }\left[\mathrm{cm}^{2}\right]}
$$

※ IC is converted to Transistor's

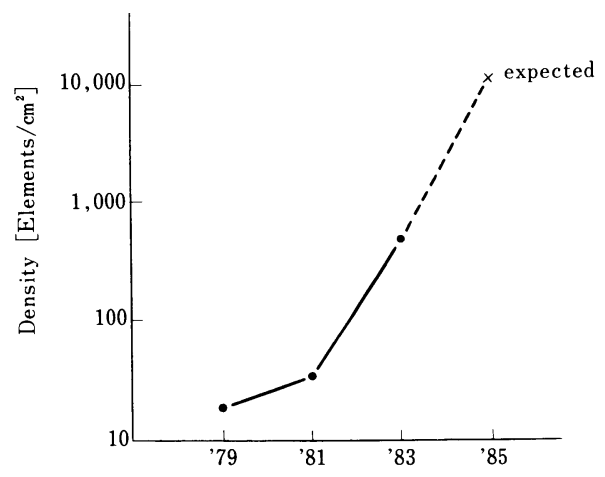

Fig. 6 Changes in Device Density of HICS (NEC)

Fig. 6は同様にその結果によるハイブリッドICの密度 (集積度) の変化例である（資料はいずれも当社例）。

Fig. 4〜Fig. 6からハイブリッドICの高密度化に対し て一つの傾向が伺える。すなわち,

i ） ハイブリッドICの実装部品の中で半導体ICのウ エイトが大きくなってくる。

ii ）半導体ICもLSI, VLSI 乞と変化していく。

iii）VLSIの実装に伴い基板は多層化が不可欠にな
Fig.4はハイブリッドICに内蔵されている半導体ICの 変遷例, Fig. 5 はその結果生じた膜基板の多層化比率推移, 
ってくる。

iV）密度の上昇は使用される半導体によるところが 大きい。

このようにVLSIは今後ハイブリッドIC と密接な関係 をもってくることが分ったが，ハイブリッド技術面では いまだ課題は多い。

\section{VLSIと 膜基板技術}

まずVLSIレべルのICを複数個内蔵したハイブリッド ICを作る場合に問題になるのは，複雑な配線を処理する 膜基板形成技術であろう。一般的に，限られた大きさの 中でハイブリッドICを実現するには,

・配線の微細化

・配線の立体化 (多層化)

が必要になってくるが, 一方では信号伝達速度の確保の 点から

・配線の低抵抗化

・配線間寄生容量の極小化 が要求されてくる。この両者は大体において相反する立 場にあり，材料をも含めたプロセスの改良開発が今後必 要である。

Tab.1にセラミック基板を使用した場合の配線の微細 化状況につき実用レベル，実験室レベルを示したが，配 線の微細化は後述の実装方法との関連で今後要求が篇し くなっていくであろう。

Tab. 1 Min. Pattern size of Wiring in HIC substrate

\begin{tabular}{c|c|c}
\hline & Practical Level & Laboratory Level \\
\hline $\begin{array}{c}\text { Thick } \\
\text { Film }\end{array}$ & 200 & 25 \\
\hline $\begin{array}{c}\text { Thin } \\
\text { Film }\end{array}$ & 30 & 5 \\
\hline
\end{tabular}

Tab. 2 An Example of Pin No. of LSI

\begin{tabular}{l|c}
\hline \multicolumn{1}{c|}{ Kinds of LSI } & Pin No. \\
\hline$\mu$-Processor & $28 \sim 40$ \\
I/O Interface & $20 \sim 40$ \\
Memory & $12 \sim 40$ \\
Gate Array & $28 \sim 2008$ \\
\hline
\end{tabular}

Vol. 1, No. 1
次に，基板の多層化であるが，八イブリッドICに実装 される半導体ICの規模, 種類および個数により端子間接 続の組合せは複雑さを増し, 基板層数の増加は避けられ ない。

Tab. 2は現在実用化されているLSIないしVLSIの機 種別Pin数の例である。ハイブリッドICはこれらICの組 合せで構成されることを考えると基板としては, ゲー トアレイで行われている PGA (Pin-Grid-Array) の規 模より遙かに複雑になってくるであろうことは想像がつ $<$ 。

ハイブリッドICのセラミック基板の場合，グリーンシ 一ト法による多層化が一般的であるが, 現在の実用レべ ルは10層位ではなかろうか。さらに高多層基板の実例や 配線のみならず抵抗体も同時形成している実例も報告さ れているが, 上述の傾向からみて将来的にも必要な技術 開発である。

VLSI 搭載に対する多層化での問題点の一つは, 現在 一般的に使用されている配線材料（WやMo）の抵抗性で あろう。高速化が進んでいるコンピュー夕用などには限 界があり，これに代る配線手段の開発が必要になってき ている。

多層化における他の問題点としては，製造例における 基板品質の確保がある。品質保証の一手段として検査が 行われるが, 現在最も一般的に行われているのは

・目視による外観検查

- 電気的通電検査

である。ハイブリッドIC用基板はプリント板に比し小形 のため前者では見落し, 後者では電気的接触不具合の発 生頻度をいかに低くしていくかが問題であろう。また後 者の場合, 通常はプローバによる直接接触法がとられ るか, 少量多品種かつ短寿命のハイブリッドICに対し高 精度を要するプローバの共通化をいかに図るかも現実的 な課題であろう。

厚膜多層基板を使用したハイブリッドICの例をFig. 7 およびFig. 8に示す。Fig. 7はLSI としてゲート・ア レイ 1 個，他にMSI，SSIを数個搭載した 3 層基板を使 用し，Fig. 8は表面にLSIとして1チップマイコン，RAM, LCD ドライバ, の 3 チップと SSIを 1 チップ, 裏面にトランジスタアレイを数チップ搭載したハイブリ ッドICであるが，使用されている基板は 7 層である。こ れらの例からも分るように, LSIレベルでもIC使用数の 増加によって配線基板の層数増加が大きく変っている。 VLSIレベルになるとICの組み合せいかんでは膨大な層 数が必要となるであろうことは容易に推測がつく。 


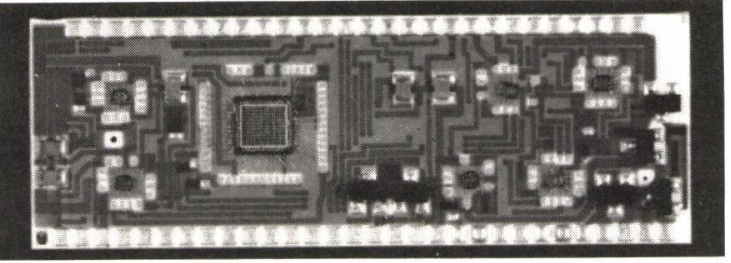

Fig. 7 Large Scale HIC with 3 Fold-Layered Substrate

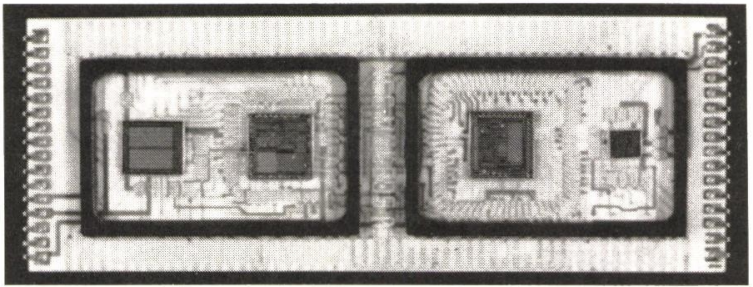

Fig. 8 Large Scale HIC with 7 Fold-Layered Substrate

\section{VLSIと実装技術}

このテーマについては，経済性と信頼性の二面をよく 検討せねばならない。周知のごとく，ハイブリッドICに 使用される半導体素子の形態にはパッケージ品と裸の千 ップの 2 通りがあり, それぞれ実装プロセスは異なって いる。

まず，パッケージ品を使用した場合であるが，メリッ トとしては,半導体素子自体についての歩留りおよび品質 が保証されることであろう。一方，デメリットとしては 実装面積が增大するためにハイブリッドICとして小形化 に難があること，その結果基板面積が大きくなり基板コ ストの上昇を招くことおよび放熱効果が悪くなりがちな こと等である。このデメリット対策として半導体パッケ 一ジの小形化（フィルムキャリヤ，チップキャリヤ等） が行われているが, 高速デバイスに対する放熱性（例之 ば, 現時点のLSIでECLゲートアレイでは10Wレベル のものがある)はVLSIになるほどさらに検討が必要で あろう。しかしながら, ハイブリッドICのコストの中で 半導体の占める割合が増加していくことを考えると, 製 造において半導体素子の歩留り, 品質の安定性および互 換性のあるこの実装法は高密度八イブリッドICの主流の 一つであろう。Fig.9 は, マイコン, EPROM等のLSI をセラミックチップキャリヤパッケージで搭載した例で ある。

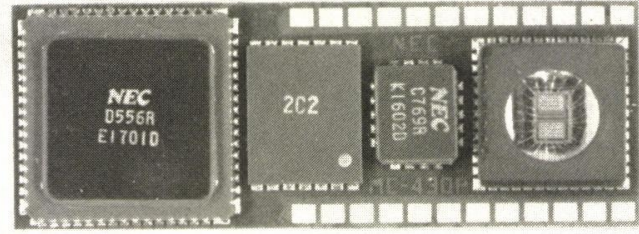

Fig. 9 Large Scale HIC by Packaged LSIS

次に, VLSI を裸のチップ状態で使用する場合には, 半導体素子そのものの性質を従来以上によく理解したう えで製品化に着手する必要がある。Fig. 1 に示したごと くVLSIでは, 集積度の向上に伴って内部素子のサイズ が小さくなり，それに伴い接合の深さも浅くなっている ためICそのものが外部要因 (環境) に対し極めてセンシ ティブになってきている。したがって現在LSI を取り 扱っている技術レべルの感覚で対処しょうとすれば，問 題が出ることは充分考えられる。

ここで, 従来の LSIレベルの素子を使用した経験をも とにして, VLSI を裸のチップ状態で使用するときの問 題点を 2,3 述べてみるが, 本件については実績にそし いため䛊りがあるかも知れない。その節はぜひご指摘い ただければ幸いである。

\section{i）不純物対策}

実装プロセス中で問題になる不純物としては樹脂中に 含まれる不純物がある。チップマウント（ダイボンディ ング）をソフトソルダで行う場合のペースト中に含ま れる不純物，モールド樹脂封止型の場合のチップ保護コ 一ト材抢よび外装樹脂材に含まれる不純物等である。

不純物としては $\mathrm{Na}^{+}, \mathrm{Cl}^{-}$が重要で,これら不純物は長 期間の製品品質即ち信頓性に大きな影響を与える。これ ら不純物の許容量はICチップのパッシベーション材質に よって異なるが, LSIの場合の例をTab.3に示した。表 に示した低不純物レベルの樹脂を使用した結果がTab. 3 下段であるが, 耐湿性の向上（ICチップの $\mathrm{Al}$ 配線溶け 対策）が著しい。VLSIの場合にはどの程度高純度が必 要かは, 今後の検討を待たねばならない。

\section{ii）放射能対策}

いわゆる $\alpha$ 線によるソフトエラー対策である。周知の ように $\alpha$ 線によりシリコン結晶中に電荷が生じメモリIC 等の䛊動作を引き起す現象であるが， $\alpha$ 線は外部から飛 来してくるものの他に使用する材料からも発生するので, この問題に対してはセラミック基板, 樹脂, 金属材料等 広範囲の検討が必要である。

\section{iii）高速化対策}


先に多層基板のところでも述べたが, 配線の抵抗成分 （比抵抗, 長さ, 厚さ, 幅) および寄生容量が高速化の 妨げとなる。したがって基板の配線のみならずICチップ と基板との接続方法も当然対象になってくる。ハイブリ

Tab. 3 Impurity Contamination of New-Developed Resin \& Its Effects for Humidity Tests (NEC)

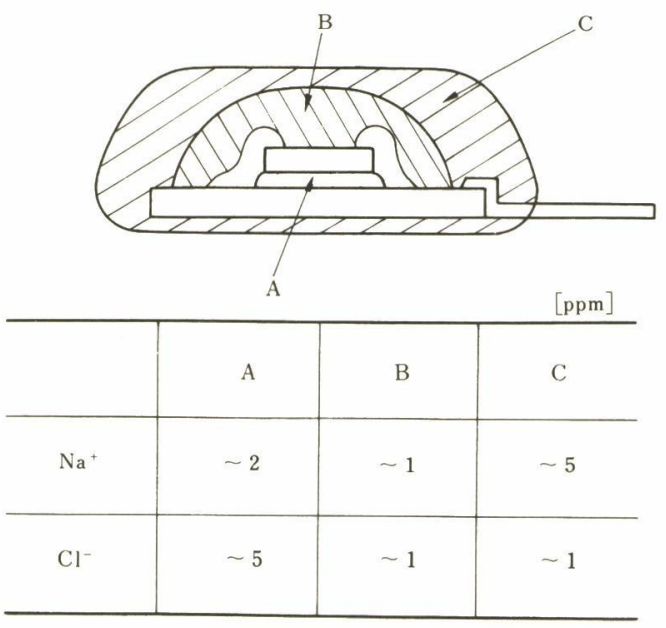

\begin{tabular}{c|c}
\hline $\mathrm{PCT}^{*}$ & $100 \mathrm{Hrs} \sim$ \\
$\left(125^{\circ} \mathrm{C}, 2.3 \mathrm{~atm}\right)$ & $1,000 \mathrm{Hrs} \sim$ \\
\hline $\begin{array}{c}\mathrm{HHBT}^{* *} \\
\left(85^{\circ} \mathrm{C}, 85 \% \mathrm{KH}\right)\end{array}$ \\
\hline
\end{tabular}

${ }^{*}$ PCT : Pressure Cooker Test

**HHBT : Hi-Temp. Humidity Biasing Test

Passive Chip

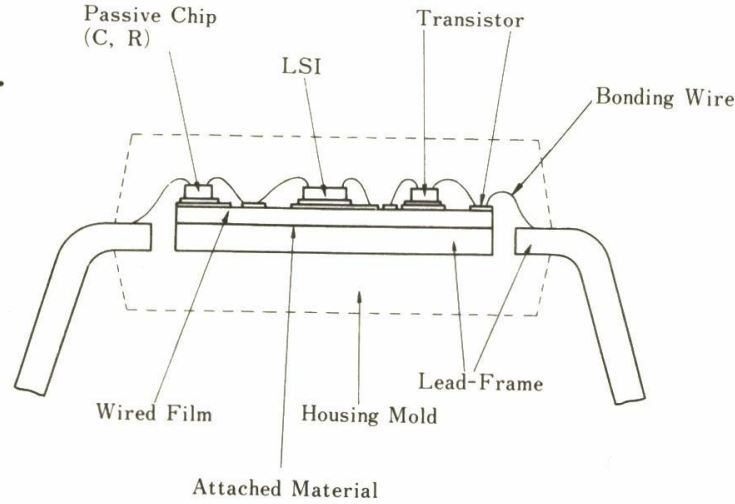

Fig. 10 Cross-section of New Type HIC (NEC)

Vol. 1, No. 1
ッドICでは Auあるいは $\mathrm{Al}$ 線によるワイヤボンディング が主流であるが、フリップチップ等を使用したワイヤレ スボンディング方式は速度のみならず実装面積の低減と いう点からも優位性が出るだろう。

\section{iv）放熱対策}

高速化に伴うICの消費電力対策も重要な項目である。 この対策として高熱伝導度基板の開発が盛んであり, セ ラミックでは窒化アルミ(AIN)（日電, 東芝) や少量のへ リリヤ添加の炭化桂素（SiC）（日立）あるいは芯材に $\mathrm{Cu}, \mathrm{Al}$ 等の金属を用い表面を酸化またはコーティング により絶縁性をもたせた基板等が実用化されている。こ れらに共通する今後の課題は, 多層化と低価格化であろう。

v) 污れ対策

i）の不純物対策同様污れ対策もまた重要である。污れ

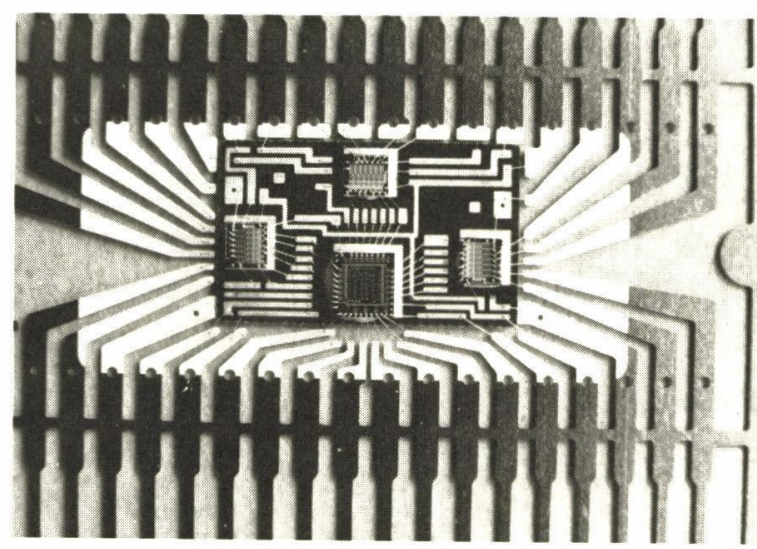

Fig. 11 Inner State of New Type HIC (NEC)

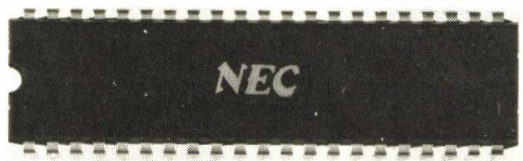

C- 42

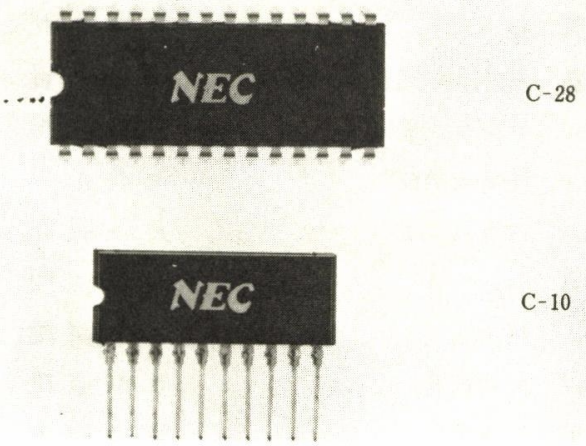

Fig. 12 Package Samples of New Type HIC (NEC) 
対策としては製造現場の環境改善も必要であるが, 工程 を短縮し污染要因に遭遇するチャンスを減らすことも大 切である。組立工程数からみると半導体 I C と八イブリ ッドICでは, 前者の方が後者より約 $30 \%$ 少ない。すなわ ち污れのチャンスは減少しているわけである。八イブリ ッドICでも一工夫が必要である。

以上VLSIを裸のチップ状態で使用する場合のハイブ リッド実装技術の課題について述べてみたが, 種々比べ てみるとどうやらハイブリッドICとしては半導体ICにお ける実装技術がそのまま適用できれば好都合であること に気がつく。最近，抵抗・コンデンサといった受動素子 を薄膜技術によりシリコンチップ化し, IC 等の能動素子 とリードフレーム上で相互接続した後トランスファモー ルドで外装した新構造のハイブリッドIC（日電）が発表 されているが，その思想は実装技術を半導体IC 組立技術 に近づけ上記i）〜v）までの問題解決の一手段としようと
したものである。Fig. 10およびFig. 11，12 は製品例で ある。

以上，紙面の都合で膜技術と実装面の課題について述 べたが,さらに重要なことにVLSIを搭載したハイブリ ッドICの特性保証, すなわち検査をどうするかの問題が ある。正直なところ，最も経済的な検查システムについ ては暗中模索の状態である。専門の方々のご意見， ご見 解をいただければ幸いである。

例之ば,

\section{参 考 文 献}

i) Proc, of The 3rd. Intn'l Microelectronic Conf. IMC '84 Tokyo。ii）「新世代のハイブリッドテクノロジー」電子材料, Vol. 23, No.5 5, '84

\section{$1984 \cdot 1985$ 年度 ISHM JAPAN役員名簿}

\section{会 長}

菅田栄治大阪大学

\section{副会長}

武藤時雄 広島工業大学

\section{理}

池上昭 日立製作所

猪 熊敏 夫 昭栄化学工業

大西洋一郎 三菱電機

窪田規日本工業技術開発研究所

清 水潤治 大阪電気通信大学

志村幸雄 工業調查会

武田義章 日本大学

立川嚴海外エレクトロニクス

伝田精一 サンケン電気

中村義一防衛大学校

二瓶公志 沖電気工業

早川征男 シャープ

原敏人富士通

半沢幹 雄 矢崎総業

菱沼幸男 日本電気
本田辰夫松下電子部品

真弓箭一鳴海製陶

三浦敬 男 東京アイシー

宮代文夫東芝

村本昭一ソニー

森木勝治 伯東

和田毅 クラリオン

\section{監 事}

長沢成之 東洋大学

岩淵正義 デュポン・ジャパン

\section{評議員}

粟根克或 シャープ

池田正義 日立化成工業

岩瀬暢男東芝

大沢光男 ソニー

大谷四郎 鹿児島日本電気

岡本明 T D K

金子恒雄 東芝

坂本道雄 伯東

柴田勲夫 沖電気工業
柴田実西進商事

常 光宇デュポン・ジャパン

鈴木和久 日立化成工業

高砂隼人 三菱電気

高橋弘隆 住友電気工業

高見沢秀男 日本電気

綱 島 瑛一 松下電子工業

津 端一 郎 長岡技術科学大学

鳥海孝公伯東

仲山文夫 村田製作所

西井昇デュポン・ジャパン

西本和 幸 松下電器産業

平賀貞太郎 東京磁気印刷

藤島 啓 村田製作所

藤田徳弥 ミクロン機器

古川学 三井東圧化学

本多進東芝

箕輪俊夫旭硝子

望月徽 $\mathrm{N} \mathrm{H} \mathrm{K}$ 放送技研

森屋邦夫武蔵野通研

山口喬 慶応義塾大学

山岸正和東京アイシー 